\title{
Prevalence of Vitamin D Deficiency and Calcium Homeostasis in Saudi Children
}

\author{
Adnan M. Al Shaikh1, Bahaa Abaalkhail2, Ashraf Soliman3, Ibrahim Kaddam1, Khalid Aseri1, \\ Yousef Al Saleh4, Ali Al Qarni5, Ahmed Al Shuaibi6, Waleed Al Tamimi4, Abdel Moniem Mukhtar2 \\ ${ }^{1}$ King Abdulaziz Medical City in Jeddah, King Saud bin Abdulaziz University for Health Sciences, Department of Pediatrics, Chemistry Laboratory, \\ Community Medicine, Jeddah, Saudi Arabia \\ 2King Abdulaziz University Hospital, Clinic of Family and Community Medicine, Jeddah, Saudi Arabia \\ 3 University of Alexandria Faculty of Medicine, Department of Pediatrics, Alexandria, Egypt \\ ${ }^{4}$ King Abdulaziz Medical City-Central, King Saud bin Abdulaziz University for Health Sciences, Department of Medicine, Chmistry Laboratory, \\ Riyadh, Saudi Arabia \\ ${ }^{5}$ King Abdulaziz University Hospital, King Abdullah International Medical Research Center, Al Hasa, Saudi Arabia \\ 6Imam Abdulrahman AlFaisal Hospital, Clinic of Family Medicine, Dammam, Saudi Arabia
}

\section{WHAT IS ALREADY KNOWN ON THIS TOPIC?}

Vitamin D deficiency in children in Saudi Arabia was reported in previous small studies in single cities in the country.

\section{WHAT THIS STUDY ADDS?}

Herein, we present our large-scale study on prevalence of vitamin D deficiency and calcium homeostasis in Saudi children and adolescents covering almost the whole country.

\section{ABSTRACT}

Objective: Vitamin D deficiency (VDD) and vitamin D insufficiency (VDI) are significant health problems all over the world. The aim of this study was to determine the prevalence of VDD and VDI in children and adolescents residing in 8 provinces in the Kingdom of Saudi Arabia and to also investigate calcium homeostasis in these subjects.

Methods: A cross-sectional study was conducted in 2110 participants aged between 6 and 15 years. Information on socio-demographic status, anthropometric measurements, knowledge about vitamin D, color of the skin, dietary intake, sun exposure experience, smoking, and physical activity were collected through a questionnaire given to the parents of all subjects. The subjects were divided into three groups as vitamin D deficient, vitamin $\mathrm{D}$ insufficient, and vitamin sufficient according to their blood level of vitamin D [VDD $\leq 25 \mathrm{nmol} / \mathrm{L}$ (25 hydroxy vitamin D), VDI >25-50 nmol/L, and VDS $>50 \mathrm{nmol} / \mathrm{L}]$.

Results: VDD was highly prevalent in this group of children. 95.3 of the subjects had either VDD (45.5\%) or VDI (49.9\%). The prevalence rate of VDD combined with VDI was higher in females (97.8\%) compared to males (92.8\%) ( $p<0.001)$. Only 1.6\% had significant hypocalcaemia. Children with dark skin had lower concentrations of vitamin D and higher concentrations of parathormone. A positive correlation was observed between 25 hydroxy vitamin $D$ level and serum calcium, inorganic phosphate, and alkaline phosphatase concentrations.

Conclusion: The results showed a high prevalence of VDD and VDI in Saudi children with significantly higher prevalence in girls. These findings necessitate the set-up of a national program for vitamin $\mathrm{D}$ supplementation and health education for this vulnerable group.

Keywords: Vitamin D, vitamin D deficiency, vitamin D insufficiency, parathyroid hormone levels, calcium, inorganic phosphate

Conflict of interest: None declared

Received: 24.04.2016

Accepted: 30.07 .2016

\section{Address for Correspondence}

Adnan M. Al Shaikh MD, King Abdulaziz Medical City in Jeddah, King Saud bin Abdulaziz University for Health Sciences, Department of Pediatrics, Chemistry Laboratory, Community Medicine, Jeddah, Saudi Arabia E-mail: shaikham@ngha.med.sa O.Journal of Clinical Research in Pediatric Endocrinology, Published by Galenos Publishing. 


\section{Introduction}

Vitamin D is an important steroid hormone with endocrine, paracrine, and autocrine effects. It is produced endogenously in the skin by exposure to ultraviolet rays or can be taken from exogenous sources such as some food items and vitamin D preparations $(1,2,3)$.

Vitamin $D$ has a crucial role in enhancing physiological functions both in skeletal and extra-skeletal tissues. Its vitamin D deficiency (VDD) and vitamin D insufficiency (VDI) are associated with many acute and chronic illnesses including disorders of calcium (Ca) metabolism, autoimmune diseases, some cancers, type 2 and type 1 diabetes mellitus, cardiovascular disease, and infectious diseases $(4,5,6)$.

Vitamin D is primarily synthesized in the skin after exposure to ultraviolet radiation (UVR) and less than $10 \%$ is derived from dietary sources. The quantity of vitamin D synthesized in the skin depends on the angle of the sun rays and thus on latitude, season, time of the day and duration of exposure. It is highest when the sun is in its zenith. However, sun exposure does not lead to any vitamin D3 production in the skin during most of the winter at latitudes above and below 33 degrees North and South. Other factors influencing cutaneous vitamin $\mathrm{D}$ production adversely are increased skin pigmentation, aging, and the topical application of sunscreens $(7,8)$. Food items which naturally contain vitamin $D$ in significant amounts are very limited (9).

VDD is diagnosed when 25 hydroxy vitamin $\mathrm{D}[25(\mathrm{OH})$ vitamin D] is $\leq 25 \mathrm{nmol} / \mathrm{L}$, while $\mathrm{VDI}$ is defined as a $25(\mathrm{OH})$ vitamin D level of $>25-50 \mathrm{nmol} / \mathrm{L}$. $25(\mathrm{OH})$ vitamin $\mathrm{D}>50$ $\mathrm{nmol} / \mathrm{L}$ is considered sufficient, with $75-150 \mathrm{nmol} / \mathrm{L}$ being the preferred range $(10,11,12)$. The 2011 Institute of Medicine (IOM) committee, in agreement with the Lawson Wilkins Pediatric Endocrine Society, targeted a serum value for $25(\mathrm{OH})$ vitamin $D$ of at least $50 \mathrm{nmol} / \mathrm{L}$ as meeting the needs of nearly all children as well as those of adults $(13,14)$. Hypovitaminosis $D$ is prevalent in the Middle East North Africa region (MENA) and in the Arab gulf countries (15). In these countries, a lack of population-based studies, as well as gaps in studies in infants, pre-pubertal children, and in adolescents hinder the development of region-specific guidelines and constitute a major obstacle to impact this chronic and most often subclinical disease $(13,16,17,18)$.

The aim of this study was to determine the prevalence of VDD and VDI in a large cohort of Saudi children and adolescents in relation to their $\mathrm{Ca}$ homeostasis. Moreover, the study assessed $\mathrm{Ca}$ homeostasis parameters and factors associated with VDD, including age, skin color, and body mass index (BMI).

\section{Methods}

The study was approved by the King Abdullah International Medical Research Center (KAIMRC) and conducted during the years 2013-2014. It included 2110 apparently healthy male and female children (1013 male, 1097 female) aged 6-15 years. The subjects were recruited from primary, intermediate, and secondary schools of the Western, Central, and Eastern regions of Saudi Arabia. These schools represent all educational levels in the country. Due to limited resources, no participants from the Northern and the Southern regions of the country could be included in this survey.

Individuals with renal, liver, and gastrointestinal disease, as well as those on any form of drug treatment with possible effect on bone metabolism (e.g. corticosteroids, anticonvulsants, and/ or thyroid hormones) were excluded.

Trained health workers helped in data collection and blood extraction. Parental consent was obtained ahead of time and covered all ethical issues related to the questionnaire and the study. All parents were given a questionnaire developed in Arabic language by the investigators and pretested and coded before the actual field work. The parents were also given a covering letter that explained the objectives of the study and included information (telephone number and emails) on the investigators for any inquires. The questionnaire included questions on sociodemographic state, anthropometric measurements, knowledge about vitamin D and VDD, skin color, dietary intake, sun exposure, smoking, and physical activity.

All participants underwent a general physical examination. Body weight to the nearest $0.1 \mathrm{~kg}$ was measured using a standard balance beam, and body height to the nearest $0.1 \mathrm{~cm}$ was measured using the Harpenden stadiometer (Holtain Ltd, Ales, UK). BMI was calculated as weight (kilograms) divided by height squared (square meters). Waist circumference was measured using anthropometric tape by determining the distance midway between the iliac crest and the lowest rib with the subject standing.

Blood samples were collected from the subjects in the 3 different regions throughout the academic year, which includes part of the summer and other seasons. Specimens were collected during the day, from 09:00 o'clock to 12:00 noon. In all samples, the serum was immediately separated and the samples were protected from light and stored at $-70^{\circ} \mathrm{C}$. The samples were then sent in ice to a central laboratory (at King Abdulaziz Medical City in Jeddah). The specimens were analyzed in the central laboratory using the same method (chemiluminescence immunoassay) within 2 weeks of blood collection.

The cutoff points of the IOM for vitamin D levels, namely, $\leq 25 \mathrm{nmol} / \mathrm{L}$ for deficiency, $>25-50 \mathrm{nmol} / \mathrm{L}$ for insufficiency, and $>50 \mathrm{nmol} / \mathrm{L}$ for sufficiency were used in the analysis of the data (10-12). Intact parathyroid hormone (PTH), Ca, inorganic phosphate $\left(\mathrm{PO}_{4}\right)$, alkaline phosphatase (ALP), and creatinine were determined in Architect machine (ABBOTT laboratories, Wiesbaden, Germany). Chemiluminescent Microparticle Immuno Assay (CMIA) was used for quantification of intact $\mathrm{PTH}$ in serum and plasma. 
The sensitivity of the chemiluminescence immunoassay is $<3.0 \mathrm{pg} / \mathrm{mL}$ and intra- and inter-assay CV percentages were $6.1 \%$ and $3.4 \%$ at a level of $69 \mathrm{pg} / \mathrm{mL}$, respectively.

The outcome variable VDD was used as continuous variable and categorical variable and was divided into three categories according to the level of $25(\mathrm{OH})$ vitamin $\mathrm{D}$, as given above.

\section{Statistical Analysis}

To describe our study population, we used frequencies and absolute numbers for categorical variables and mean \pm standard deviation values. Median and inter-quartile range values were used for continuous variables. Association between two categorical variables were assessed using the chi-squared test or the Fisher exact test when the data are sparse in one or more category. Associations between continuous variables were examined using either student's t-test for unpaired samples or one-way analysis of variance (ANOVA), as appropriate. Linear regression equation was used to investigate possible relations between the different variables. For all statistical tests, a p-value of $<0.05$, two tail probability was accepted as significant. We used the Statistical Package for Social Sciences version 19 for data analysis.

\section{Results}

In this cross-sectional study of a large cohort of children of ages 6 and 15 years, the overall prevalence of combined VDD and VDI was $95.3 \%$ and that of vitamin D sufficiency only $4.7 \%$. The prevalence in females $(97.8 \%)$ was significantly higher than in males $(92.8 \%)$. VDD $[25(\mathrm{OH})$ vitamin $\mathrm{D} \leq 25$ $\mathrm{nmol} / \mathrm{L}]$ was detected more frequently in females (63.9\%) than in males (25.6\%) (Table 1). VDD was more prevalent in the older age groups $(47.2 \%)$ than in the younger groups (29.9\%) as shown in Table 1.

As shown in Table 2, comparisons between two age groups (6-12 years versus 13-15 years) showed that the younger group had a higher mean $25(\mathrm{OH})$ vitamin D level $(33.1 \pm 12.2 \mathrm{nmol} / \mathrm{L})$ compared to the older group $(27.6 \pm 11.4 \mathrm{nmol} / \mathrm{L})$. Circulating PTH concentrations were significantly higher in the older group.

\begin{tabular}{|c|c|c|c|c|}
\hline $\begin{array}{l}\text { Gender and } \\
\text { age }\end{array}$ & Number & $\begin{array}{l}\leq 25 \\
\mathrm{nmol} / \mathrm{L}\end{array}$ & $\begin{array}{l}25-50 \\
\mathrm{nmol} / \mathrm{L}\end{array}$ & $\begin{array}{l}>50 \\
\mathrm{nmol} / \mathrm{L}\end{array}$ \\
\hline $\begin{array}{l}\text { Gender* } \\
\text { Males } \\
\text { Females }\end{array}$ & $\begin{array}{l}1013 \\
1097\end{array}$ & $\begin{array}{l}259(25.6 \%) \\
701(63.9 \%)\end{array}$ & $\begin{array}{l}681(67.2 \%) \\
372(33.9 \%)\end{array}$ & $\begin{array}{l}73(7.2 \%) \\
24(2.2 \%)\end{array}$ \\
\hline $\begin{array}{l}\text { Age group\# } \\
6-12 \text { years } \\
13-15 \text { years }\end{array}$ & $\begin{array}{l}204 \\
1906\end{array}$ & $\begin{array}{l}61(29.9 \%) \\
899(47.2 \%)\end{array}$ & $\begin{array}{l}123(60.3 \%) \\
930(48.8 \%)\end{array}$ & $\begin{array}{l}20(9.8 \%) \\
77(4.0 \%)\end{array}$ \\
\hline Total & 2110 & $960(45.5 \%)$ & $1053(49.9 \%)$ & $97(4.6 \%)$ \\
\hline \multicolumn{5}{|c|}{$\begin{array}{l}{ }^{*} \text { Chi-square test, } p<0.05, p \text {-value is significant for all three levels of } 25(\mathrm{OH}) \text { Vitamin } D \\
\text { \#Chi-square test, } p<0.05, p \text {-value is significant for all three levels of } 25(\mathrm{OH}) \text { Vitamin } D\end{array}$} \\
\hline
\end{tabular}

Serum $\mathrm{Ca}$ and $\mathrm{PO}_{4}$ concentrations did not differ significantly between the two groups. None of the children in the young group had hypocalcemia defined as a serum Ca level of $<2.1$ $\mathrm{nmol} / \mathrm{L}$, while $0.8 \%$ of the older group had hypocalcemia.

Children with VDD ( $\leq 25 \mathrm{nmol} / \mathrm{L})$ had significantly higher PTH concentrations and lower $\mathrm{PO}_{4}$ levels compared to those with higher $25(\mathrm{OH})$ vitamin D concentrations. Serum Ca levels did not differ between the two groups. Lower serum $\mathrm{PO}_{4}$ and higher PTH levels were observed in patients indicative of the presence of a compensatory response to low $25(\mathrm{OH})$ vitamin $\mathrm{D}$ levels (Table 3).

The degree of skin darkness of all children and adolescents was assessed and divided into 3 grades where 1=light (white), $2=$ brown, and 3 is black (Tables 4, 5). Comparison between the different groups according to their skin color revealed that children with black skin (group 3 ) had significantly lower $25(\mathrm{OH})$ vitamin D and higher PTH and ALP levels compared to those with lighter skin (ANOVA, $p<0.001$ ).

In this study, $47.1 \%$ of children and adolescents were not receiving any supplements of vitamin $D, 16.5 \%$ were taking no

\begin{tabular}{|c|c|c|c|}
\hline Variable & $\begin{array}{l}\text { Age } 6-12 \text { years } \\
\mathrm{n}=184 \\
\text { Mean (standard } \\
\text { deviation) }\end{array}$ & $\begin{array}{l}\text { Age } 13-15 \text { years } \\
n=1829 \\
\text { Mean (standard } \\
\text { deviation) }\end{array}$ & p-value \\
\hline AST (IU/L) & $20.1(7.0)$ & $16.3(7.3)$ & 0.049 \\
\hline ALT (IU/L) & $4.9(4.0)$ & $4.6(5.4)$ & 0.914 \\
\hline GGT (IU/L) & $14.6(8.1)$ & $14.8(7.3)$ & 0.013 \\
\hline $\begin{array}{l}\text { Urea nitrogen } \\
\text { (mmol/L) }\end{array}$ & $3.8(1.0)$ & $3.7(1.0)$ & 0.018 \\
\hline $\begin{array}{l}\text { Creatinine } \\
(\mu \mathrm{mol} / \mathrm{L})\end{array}$ & $53.1(7.1)$ & $59.7(17.5)$ & 0.044 \\
\hline Albumin (g/L) & $42.5(2.0)$ & $44.0(2.8)$ & 0.576 \\
\hline PTH (pg/mL) & $53.1(32.7)$ & $62.0(48.5)$ & 0.019 \\
\hline $\begin{array}{l}\text { Calcium } \\
\text { (mmol/L) }\end{array}$ & $2.39(0.1)$ & $2.4(0.1)$ & 0.090 \\
\hline $\begin{array}{l}\text { Phosphate } \\
\text { (mmol/L) }\end{array}$ & $1.6(0.2)$ & $1.5(0.2)$ & 0.110 \\
\hline ALP (IU/L) & $238.5(58.9)$ & 219.6 (102.2) & 0.715 \\
\hline BMI & $18.0(4.2)$ & $21.5(6.9)$ & 0.979 \\
\hline $\begin{array}{l}25(\mathrm{OH}) \text { vitamin } \\
\mathrm{D}(\mathrm{nmol} / \mathrm{L})\end{array}$ & 33.1 (12.2) & 27.6 (11.4) & 0.001 \\
\hline \multicolumn{4}{|c|}{$\begin{array}{l}\text { "Independent student's t-test } \\
\text { AST: aspartate transaminase, ALT: alanine transaminase, GGT: gamma glutamyl } \\
\text { transpeptidase, PTH: parathyroid hormone, ALP: alkaline phosphatase, BMI: body } \\
\text { mass index, 25(OH) vitamin D: } 25 \text { hydroxy vitamin D }\end{array}$} \\
\hline
\end{tabular}


milk or milk products, while $8.6 \%$ were taking milk less than once weekly. In $29 \%$ of the cohort, no exposure to the sun at any time was reported (Table 5) and $27 \%$ of the subjects were reported to wear complete covering clothes including the face and hands. In those who reported being exposed to the sun, $52 \%$ reported exposure at less efficient times for UV rays

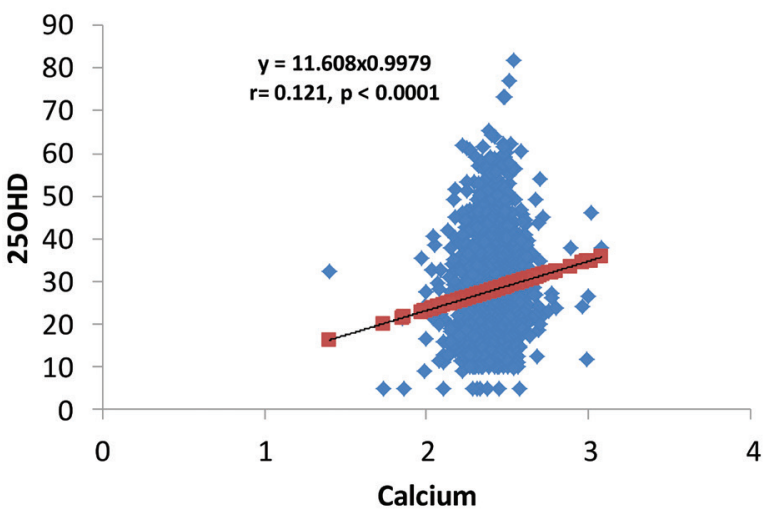

Figure 1. Regression of Vitamin D level on calcium concentration in population

\begin{tabular}{|c|c|c|c|}
\hline Variable & $\begin{array}{l}25(\mathrm{OH}) \text { Vitamin } \\
\mathrm{D} \leq 25 \\
\mathrm{n}=960 \\
\text { Mean (standard } \\
\text { deviation) }\end{array}$ & $\begin{array}{l}25(\mathrm{OH}) \text { Vitamin } \\
\mathrm{D}>25 \\
\mathrm{n}=1150 \\
\text { Mean (standard } \\
\text { deviation) }\end{array}$ & p-value\# \\
\hline AST (IU/L) & $16.0(6.8)$ & $17.4(7.8)$ & 0.001 \\
\hline ALT (IU/L) & $4.3(4.9)$ & $4.9(5.6)$ & 0.914 \\
\hline GGT (IU/L) & $14.3(7.3)$ & $15.2(7.5)$ & 0.013 \\
\hline $\begin{array}{l}\text { Urea nitrogen } \\
\text { (mmol/L) }\end{array}$ & $3.5(0.9)$ & $4.0(1.0)$ & 0.018 \\
\hline $\begin{array}{l}\text { Creatinine } \\
(\mu \mathrm{mol} / \mathrm{L})\end{array}$ & 58.4 (17.3) & $59.6(16.5)$ & 0.044 \\
\hline Albumin (g/L) & $43.9(2.5)$ & $43.8(3.0)$ & 0.576 \\
\hline $\mathrm{PTH}^{* *}(\mathrm{pg} / \mathrm{mL})$ & $72.0(56.8)$ & $52.0(35.0)$ & 0.019 \\
\hline $\begin{array}{l}\text { Calcium } \\
\text { (mmol/L) } \\
(\mathrm{mmol} / \mathrm{L})\end{array}$ & $2.39(0.1)$ & $2.4(0.1)$ & 0.09 \\
\hline $\begin{array}{l}\text { Phosphate } \\
\text { (mmol/L) }\end{array}$ & $1.3(0.2)$ & $1.5(0.2)$ & 0.011 \\
\hline ALP (IU/L) & 209.5 (105.9) & $232.1(91.0)$ & 0.715 \\
\hline BMI & $21.9(8.0)$ & $20.6(5.4)$ & 0.979 \\
\hline Age (years) & $13.1(1.6)$ & $12.7(1.8)$ & 0.002 \\
\hline \multicolumn{4}{|c|}{$\begin{array}{l}\text { \#Independent student's t-test } \\
\text { AST: aspartate transaminase, ALT: alanine transaminase, GGT: gamma glutamyl } \\
\text { transpeptidase, PTH: parathyroid hormone, ALP: alkaline phosphatase, BMI: body } \\
\text { mass index, 25(OH) vitamin D: } 25 \text { hydroxy vitamin D }\end{array}$} \\
\hline
\end{tabular}

(early morning and late afternoon) and 10\% reported use of sun-screening creams.

Correlation analyses revealed that $25(\mathrm{OH})$ vitamin $\mathrm{D}$ levels correlated significantly with Ca level $(r=0.15, p<0.001)$ (Figure 1) and negatively with PTH (Figure 2), age, and BMI. A positive correlation was observed between PTH and ALP levels ( $r=0.23$, $\mathrm{p}<0.001$ ) (Figure 3).

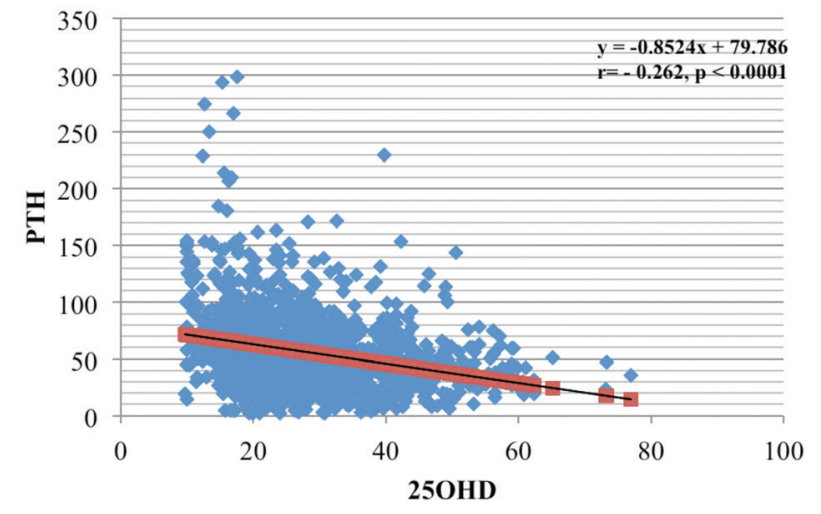

Figure 2. Regression of Vitamin $D$ on parathyroid hormone level in population $<15$ years

\begin{tabular}{|c|c|c|c|}
\hline \multirow{2}{*}{\multicolumn{2}{|c|}{ Variable }} & \multicolumn{2}{|c|}{ 25(OH) Vitamin D (nmol/L) } \\
\hline & & \multirow{2}{*}{$\begin{array}{l}\leq 25 \\
310(41.4)\end{array}$} & \multirow{2}{*}{$\begin{array}{l}>25 \\
438(58.6)\end{array}$} \\
\hline \multirow{3}{*}{ Region* } & Western & & \\
\hline & Eastern & $313(51.2)$ & $298(48.8)$ \\
\hline & Central & $337(44.9)$ & $414(55.1)$ \\
\hline \multirow{2}{*}{ Gender* } & Male & $259(25.6)$ & $754(74.4)$ \\
\hline & Female & $701(63.9)$ & $396(36.1)$ \\
\hline \multirow{2}{*}{ Sun* exposure } & Yes & $626(43.4)$ & $817(56.6)$ \\
\hline & No & $298(51.0)$ & $286(49.0)$ \\
\hline \multirow{2}{*}{ Exercise* } & Yes & $268(35.1)$ & $495(64.9)$ \\
\hline & No & $380(54.2)$ & $321(45.8)$ \\
\hline \multirow{2}{*}{ Vitamin* supplements } & Yes & $521(49.3)$ & $536(50.7)$ \\
\hline & No & $393(41.6)$ & $552(58.4)$ \\
\hline \multirow{3}{*}{ Skin color* } & White & $300(44.8)$ & $369(55.2)$ \\
\hline & Brown & $635(45.7)$ & $755(54.3)$ \\
\hline & Black & $7(87.5)$ & $1(12.5)$ \\
\hline \multirow{2}{*}{$\mathrm{BMI}^{*}$} & $<95^{\text {th }} \%$ & $862(44.6)$ & $1072(55.4)$ \\
\hline & $\geq 95^{\text {th }} \%$ & $88(58.7)$ & $62(41.3)$ \\
\hline \multirow{2}{*}{$\operatorname{Age}^{*}$} & $6-12$ & $61(29.9)$ & $143(70.1)$ \\
\hline & $13-15$ & $899(47.2)$ & $1007(52.8)$ \\
\hline
\end{tabular}


Table 5. Relationship between vitamin $\mathrm{D}$ and other biochemical data according to skin color

\begin{tabular}{|c|c|c|c|c|}
\hline $\begin{array}{l}\text { Skin color } \\
\text { variable }\end{array}$ & $\begin{array}{l}\text { White } \\
\mathrm{n}=669 \\
\text { Mean } \\
\text { (standard } \\
\text { deviation) }\end{array}$ & $\begin{array}{l}\text { Brown } \\
\mathrm{n}=1390 \\
\text { Mean } \\
\text { (standard } \\
\text { deviation) }\end{array}$ & $\begin{array}{l}\text { Black } \\
\mathrm{n}=8 \\
\text { Mean } \\
\text { (standard } \\
\text { deviation) }\end{array}$ & p-value \# \\
\hline AST (IU/L) & $16.5(7.8)$ & $16.7(6.8)$ & $17.7(4.8)$ & 0.803 \\
\hline ALT (IU/L) & $4.5(4.8)$ & $4.6(4.7)$ & $4.6(4.9)$ & 0.960 \\
\hline GGT (IU/L) & $14.5(6.8)$ & $14.8(7.3)$ & $24.4(16.3)$ & 0.001 \\
\hline $\begin{array}{l}\text { Urea nitrogen } \\
(\mathrm{mmol} / \mathrm{L})\end{array}$ & $3.7(1.0)$ & $3.8(1.0)$ & $2.7(0.6)$ & 0.015 \\
\hline $\begin{array}{l}\text { Creatinine } \\
(\mu \mathrm{mol} / \mathrm{L})\end{array}$ & $58.5(7.2)$ & $59.4(20.1)$ & $56.2(8.1)$ & 0.525 \\
\hline Albumin (g/L) & $43.9(2.9)$ & $43.8(2.7)$ & $44.6(2.5)$ & 0.587 \\
\hline PTH (pg/ml) & $56.4(37.2)$ & $62.7(50.3)$ & 136.1 (141.4) & 0.001 \\
\hline $\begin{array}{l}\text { Calcium } \\
\text { (mmol/L) }\end{array}$ & $2.4(0.1)$ & $2.4(0.1)$ & $2.4(0.1)$ & 0.377 \\
\hline $\begin{array}{l}\text { Phosphate } \\
\text { (mmol/L) }\end{array}$ & $1.5(0.2)$ & $1.5(0.2)$ & $1.5(0.4)$ & 0.177 \\
\hline ALP (IU/L) & $\begin{array}{l}208.4 \\
(99.4)\end{array}$ & $226.8(98.1)$ & $270.3(108.5)$ & 0.001 \\
\hline $\begin{array}{l}25(\mathrm{OH}) \text { vitamin } \\
\mathrm{D}(\mathrm{nmol} / \mathrm{L})\end{array}$ & $28.6(12.1)$ & $28.1(11.3)$ & $20.8(13.8)$ & 0.127 \\
\hline
\end{tabular}

\#Analysis of variance (ANOVA test)

AST: aspartate transaminase, ALT: alanine transaminase, GGT: gamma glutamyl transpeptidase, PTH: parathyroid hormone, ALP: alkaline phosphatase, BMI: body mass index, $25(\mathrm{OH})$ vitamin $\mathrm{D}: 25$ hydroxy vitamin $D$

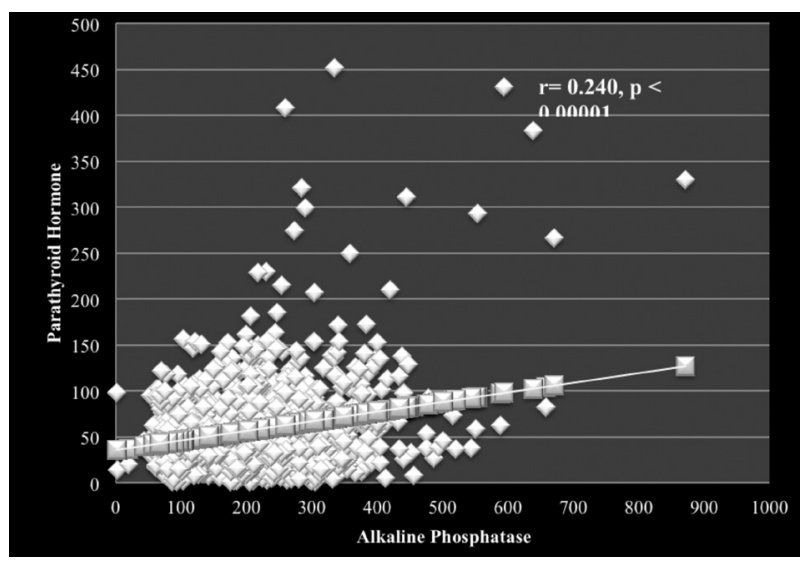

Figure 3. Regression of parathyroid hormone on alkaline phosphatase concentrations in population $<15$ years

\section{Discussion}

Vitamin D is critical for Ca homeostasis and for mineralization of the skeleton, especially during periods of rapid growth, namely, growth in infancy, childhood, and pubertal period.
Without vitamin D, only $10-15 \%$ of dietary Ca and about $60 \%$ of phosphorus are absorbed. The active form, 1,25-dihydroxy vitamin $D\left[1,25-(\mathrm{OH})_{2} \mathrm{D}_{3}\right]$ markedly increases the efficiency of intestinal $\mathrm{Ca}$ and phosphorus absorption. Serum levels of $25(\mathrm{OH})$ vitamin $\mathrm{D}$ below $50 \mathrm{nmol} / \mathrm{L}$ are associated with a significant decrease in intestinal Ca absorption. In children, adolescents, and adults, this is associated with increased PTH and decreased insulin-like growth factor 1 (IGF-1) secretion. Serum levels of $25(\mathrm{OH})$ vitamin $\mathrm{D}$ are directly related to bone mineral density with a maximum density achieved when the $25(\mathrm{OH})$ vitamin D level reaches $100 \mathrm{nmol} / \mathrm{L}(40 \mathrm{ng} / \mathrm{mL}$ ) or more. Severe and/or prolonged VDD is associated with impaired linear growth and the development of many skeletal disorders including rickets, osteomalacia, and fractures. In addition, many extra-skeletal disorders have been associated with VDD. An increasing body of evidence also shows the extra-skeletal benefits of vitamin $D$, such as those on the immune system, fuel metabolism, cardiovascular system, and cancer. In addition, associations with decreased mortality have been reported (13, $17,18,19,20,21,22,23,24,25,26,27,28,29)$.

The results of this study showed a very high prevalence of VDD and VDI in the majority of children and adolescents between 6 and 15 years of age in a sunny country such as the Kingdom of Saudi Arabia. Several large-sample populationsbased studies as well as smaller studies also revealed a high prevalence of hypovitaminosis $D$ and of rickets in infants (0.5\% of Saudis <2 years) and adolescents in Saudi Arabia $(21,22,23,24,25,30)$.

While rickets is almost eradicated in western populations, its prevalence remains unacceptably high in Asia, Africa, and the Middle East and resurgence is also registered in ethnic minority groups in some Northern European countries despite its plentiful sunshine. Such findings are explained by the prevalence of specific risk factors for hypovitaminosis D in this region. These include lifestyle factors, namely lack of sunlight exposure (because of very hot weather) (29\% of our cohort) or exposure during the wrong time of the day ( $52 \%$ of our cohort) and inadequate use of vitamin D supplements $(47 \%$ of our cohort) are well recognized major determinants of circulating $25(\mathrm{OH})$ Vit D levels.

Many studies reported significant lack of sun exposure and lack of vitamin D supplementation in the Arab Gulf region $(26,27,28,29,31,32)$. A study conducted in Riyadh city which included 808 Saudi children and 561 adults of both genders showed that subjects who had a sun exposure of $<20 \mathrm{~min}$ and who were of dark skin had the highest prevalence of VDD (33). In our study, data on duration of sun exposure, time of exposure, clothing, using sun protection substances were also collected. These factors working independently or interacting with each other will be analyzed in reference to skin color in future papers.

It has been reported that genetic factors may contribute to up to $50 \%$ of inter-individual variability in serum $25(\mathrm{OH})$ 
vitamin D levels and in $27 \%$ of Saudi patients (32). The study done by Baroncelli et al (34) on 98 rachitic children conducted in Egypt and Turkey showed that VDD and rickets in the Middle East countries was determined, in addition to nutritional and environmental factors, also by genetic predisposition factors. They found that vitamin D receptor genotypes may predispose to rickets by increased frequency of the $\mathrm{F}$ allele.

In our study and also in other studies, females had more prevalent VDD compared to males. In adolescents and adults, this finding may be due to the more restricted outdoors activity of the females and the conservative clothing they wear that prevent exposure to the sun rays. In addition, lack of awareness of the importance of sun exposure for bone health and for cosmetic reasons (avoiding darkening of their skin) including using sun-screening agents are other important factors.

A very recent study in children and adolescents from Iran to determine the reference intervals for vitamin $D$ and other 12 biochemical indices showed the cutoff level for VDD to be 50 $\mathrm{nmol} / \mathrm{L}$ (35). We also used this cutoff point in our study and found a high prevalence of VDD in our population despite the sunshine all the year around, a finding which can be associated with the influence of other interacting risk factors that need to be investigated in further studies.

The majority of the children with VDD in our cohort, even those with severe VDD $[25(\mathrm{OH})$ vitamin $D<25 \mathrm{nmol} / \mathrm{L}]$, had normal serum $\mathrm{Ca}, \mathrm{PO}_{4}$, and ALP levels. The development of clinical manifestations of VDD rickets and osteomalacia depends on many factors apart from the severity and duration of the VDD. A potent adaptation process, mediated by the PTH and the IGF-1 modifies the clinical and radiological manifestations of VDD $(12,13)$. Therefore, overt cases of rickets and osteomalacia represent only the tip of the iceberg of patients with severe VDD and may indicate a defect in adaptation. It is also noteworthy that when clinical rickets develops, the entire process occurs rapidly, within a few months. This potent adaptation process, brought about by increased PTH secretion, explains the normal Ca level of our black children and adolescents despite their significantly low $25(\mathrm{OH})$ vitamin D levels. In addition, this same adaptation process explains the relatively low incidence of florid rickets and osteomalacia in the presence of a high prevalence of VDD. In support of this view, the children in our cohort with $25(\mathrm{OH})$ vitamin $\mathrm{D}<25 \mathrm{nmol} / \mathrm{L}$ values have significantly higher $\mathrm{PTH}$ and lower $\mathrm{PO}_{4}$ levels (due to the phosphaturic effect of $\mathrm{PTH}$ ), to maintain their $\mathrm{Ca}$ levels within the normal range. Consequently, VDD in adolescents may be asymptomatic and go undetected. These patients usually present with vague manifestations including pain in weight-bearing joints (back, thighs, calves), difficulty in walking, running and/or climbing stairs, getting up from a squatting position, and muscle cramps. Facial twitches and carpo-pedal spasms are less frequent symptoms. Due to the demineralization of bones, deformities such as triradiate pelvis, lordosis, and/or genu valgus or varus may develop. These manifestations may go unnoticed for long periods. In severe and prolonged deficiency, vertebral compression fractures and fractures of the long bones may occur. Moreover, VDD can be misdiagnosed as fibromyalgia, chronic fatigue syndrome, or simply depression in adolescents $(13,36,37)$.

In conclusion, VDD is highly prevalent in Saudi children, both in females and males. Most of the cases are asymptomatic or may present with vague and non-specific symptoms. These data urge pediatricians and physicians to have a higher degree of clinical suspicion for VDD and to screen all the patients with non-specific musculoskeletal pain by measuring $25(\mathrm{OH})$ vitamin $D$ level. Food fortification with vitamin $D$ and health education in schools and media to improve sun exposure appear to be very important steps to correct this prevalent deficiency and prevent its short- and long-term deleterious consequences. In addition, regular screening of children for VDD and initiation of treatment at an early stage are important measures for prevention of the undesirable consequences of VDD.

\section{Ethics}

Ethics Committee Approval: King Abdullah International Medical Research Center (KAIMRC), Jeddah, Saudi Arabia 2012-2013, Informed Consent: It was taken.

Peer-review: Internally peer-reviewed.

\section{Authorship Contributions}

Concept: Adnan M. Al Shaikh, Bahaa Abaalkhail, Ashraf Soliman, Ibrahim Kaddam, Khalid Aseri, Yousef Al Saleh, Ali Al Qarni, Ahmed Al Shuaibi, Waleed Al Tamimi, Abdel Moniem Mukhtar, Design: Adnan M. Al Shaikh, Bahaa Abaalkhail, Ashraf Soliman, Ibrahim Kaddam, Khalid Aseri, Yousef Al Saleh, Ali Al Qarni, Ahmed Al Shuaibi, Waleed Al Tamimi, Abdel Moniem Mukhtar, Data Collection or Processing: Adnan M. Al Shaikh, Bahaa Abaalkhail, Ashraf Soliman, Ibrahim Kaddam, Khalid Aseri, Yousef Al Saleh, Ali Al Qarni, Ahmed Al Shuaibi, Waleed Al Tamimi, Abdel Moniem Mukhtar, Analysis or Interpretation: Adnan M. Al Shaikh, Bahaa Abaalkhail, Ashraf Soliman, Ibrahim Kaddam, Khalid Aseri, Yousef Al Saleh, Ali Al Qarni, Ahmed Al Shuaibi, Waleed Al Tamimi, Abdel Moniem Mukhtar, Literature Search: Adnan M. Al Shaikh, Bahaa Abaalkhail, Ashraf Soliman, Ibrahim Kaddam, Khalid Aseri, Yousef Al Saleh, Ali Al Qarni, Ahmed Al Shuaibi, Waleed Al Tamimi, Abdel Moniem Mukhtar, Writing: Adnan M. Al Shaikh, Bahaa Abaalkhail, Ashraf Soliman, Ibrahim Kaddam, Khalid Aseri, Yousef Al Saleh, Ali Al Qarni, Ahmed Al Shuaibi, Waleed Al Tamimi, Abdel Moniem Mukhtar.

Financial Disclosure: The authors declared that this study received no financial support.

\section{References}

1. Holick MF Sunlight, UV-radiation, vitamin D and skin cancer: how much sunlight do we need? Adv Exp Med Biol 2008;624:1-15.

2. Wacker M, Holick MF. Sunlight and Vitamin D: A global perspective for health. Dermatoendocrinol 2013;5:51-108. 
3. Holick MF Vitamin D: evolutionary, physiological and health perspectives. Curr Drug Targets 2011;12:4-18.

4. Wacker M, Holick MF. Vitamin D-effects on skeletal and extraskeletal health and the need for supplementation. Nutrients 2013;5:111-148.

5. Grober U, Spitz J, Reichrath J, Kisters K, Holick MF Vitamin D: Update 2013: From rickets prophylaxis to general preventive healthcare. Dermatoendocrinol 2013;5:331-347. Epub 2013 Nov 5

6. Gennari C. Calcium and vitamin D nutrition and bone disease of the elderly. Public Health Nutr 2001;4:547-559.

7. Holick MF Vitamin D and health: evolution, biologic functions, and recommended dietary intakes for vitamin D. Vitamin D: Springer 2010:3:33.

8. Holick MF, Chen TC. Vitamin D deficiency: a worldwide problem with health consequences. Am J Clin Nutr 2008;87:1080-1086.

9. Holick MF Vitamin D deficiency. N Engl J Med 2007;357:266-281.

10. Holick MF, Binkley NC, Bischoff-Ferrari HA, Gordon CM, Hanley DA, Heaney RP, Murad MH, Weaver CM, Endocrine S. Evaluation, treatment, and prevention of vitamin $\mathrm{D}$ deficiency: an Endocrine Society clinical practice guideline. J Clin Endocrinol Metab 2011;96:1911-1930. Epub 2011 Jun 6

11. Rosen CJ, Abrams SA, Aloia JF, Brannon PM, Clinton SK, DurazoArvizu RA, Gallagher JC, Gallo RL, Jones G, Kovacs CS, Manson JE, Mayne ST, Ross AC, Shapses SA, Taylor CL. IOM committee members respond to Endocrine Society vitamin D guideline. J Clin Endocrinol Metab 2012;97:1146-1152. Epub 2012 Mar 22

12. Bouillon R, Van Schoor NM, Gielen E, Boonen S, Mathieu C, Vanderschueren D, Lips P. Optimal vitamin D status: a critical analysis on the basis of evidence-based medicine. J Clin Endocrinol Metab 2013;98:1283-1304.

13. Root A, Diamond F. Calcium metabolism, normal homeostasis and disorders of calcium metabolism in the child and adolescent. Pediatric Endocrinology 2nd ed. Philadelphia, Saunders, 2002;65-110.

14. Misra M, Pacaud D, Petryk A, Collett-Solberg PF, Kappy M, Drug, Therapeutics Committee of the Lawson Wilkins Pediatric Endocrine S. Vitamin D deficiency in children and its management: review of current knowledge and recommendations. Pediatrics 2008;122:398417.

15. Chakraborty G, Leach T, Zanakis MF, Ingoglia NA. Posttranslational protein modification by amino acid addition in regenerating optic nerves of goldfish. J Neurochem 1986;46:726-732.

16. Ross A, Taylor C, Yaktine A, Del Valle H. Dietary reference intakes for vitamin $\mathrm{D}$ and calcium. Washington (DC), Natl Academies Press (US), 2011:35-74.

17. Soliman AT, Al Khalaf F, Alhemaidi N, Al Ali M, Al Zyoud M, Yakoot K. Linear growth in relation to the circulating concentrations of insulinlike growth factor I, parathyroid hormone, and 25-hydroxy vitamin D in children with nutritional rickets before and after treatment: endocrine adaptation to vitamin D deficiency. Metabolism 2008;57:95-102.

18. Holick MF. Resurrection of vitamin D deficiency and rickets. J Clin Invest 2006;116:2062-2072.

19. Heaney RP, Dowell MS, Hale CA, Bendich A. Calcium absorption varies within the reference range for serum 25 -hydroxyvitamin D. J Am Coll Nutr 2003;22:142-146.

20. Zittermann A, lodice S, Pilz S, Grant WB, Bagnardi V, Gandini S. Vitamin $D$ deficiency and mortality risk in the general population: a meta-analysis of prospective cohort studies. Am J Clin Nutr 2012;95:91-100. Epub 2011 Dec 14
21. Ardawi MS, Sibiany AM, Bakhsh TM, Qari MH, Maimani AA. High prevalence of vitamin $D$ deficiency among healthy Saudi Arabian men: relationship to bone mineral density, parathyroid hormone, bone turnover markers, and lifestyle factors. Osteoporos Int 2012;23:675686. Epub 2011 Apr 6

22. Kanan RM, Al Saleh YM, Fakhoury HM, Adham M, Aljaser S, Tamimi W. Year-round vitamin D deficiency among Saudi female out-patients. Public Health Nutr 2013;16:544-548. Epub 2012 Jun 13

23. Elsammak MY, Al-Wossaibi AA, Al-Howeish A, Alsaeed J. High prevalence of vitamin $D$ deficiency in the sunny Eastern region of Saudi Arabia: a hospital-based study. East Mediterr Health J 2011;17:317-322.

24. Al-Elq AH, Sadat-Ali M, Al-Turki HA, Al-Mulhim FA, Al-Ali AK. Is there a relationship between body mass index and serum vitamin $D$ levels? Saudi Med J 2009;30:1542-1546.

25. Al-Turki HA, Sadat-Ali M, Al-Elq AH, Al-Mulhim FA, Al-Ali AK. 25-Hydoxyvitamin D levels among healthy Saudi Arabian women. Saudi Med J 2008;29:1765-1768.

26. Abdullah MA, Salhi HS, Bakry LA, Okamoto E, Abomelha AM, Stevens B, Mousa FM. Adolescent rickets in Saudi Arabia: a rich and sunny country. J Pediatr Endocrinol Metab 2002;15:1017-1025.

27. GE-H Fuleihan. Vitamin D deficiency in the Middle East and its health consequences for children and adults. Clin Rev Bone Miner Metab 2009; 7:77-93.

28. Al-Atawi MS, Al-Alwan IA, Al-Mutair AN, Tamim HM, Al-Jurayyan NA. Epidemiology of nutritional rickets in children. Saudi J Kidney Dis Transpl 2009;20:260-265.

29. Al-Mustafa ZH, Al-Madan M, Al-Majid HJ, Al-Muslem S, Al-Ateeq S, Al-Ali AK. Vitamin D deficiency and rickets in the Eastern Province of Saudi Arabia. Ann Trop Paediatr 2007;27:63-67.

30. AlBuhairan FS. Adolescent and Young Adult Health in the Arab Region: Where We Are and What We Must Do. J Adolesc Health 2015;57:249-251.

31. Siddiqui AM, Kamfar HZ. Prevalence of vitamin D deficiency rickets in adolescent school girls in Western region, Saudi Arabia. Saudi Med J 2007;28:441-444

32. Shea MK, Benjamin EJ, Dupuis J, Massaro JM, Jacques PF, D'Agostino RB, Sr., Ordovas JM, O'Donnell CJ, Dawson-Hughes B, Vasan RS, Booth SL. Genetic and non-genetic correlates of vitamins K and D. Eur J Clin Nutr 2009;63:458-464. Epub 2007 Nov 21

33. Al-Daghri NM, Al-Saleh Y, Khan N, Sabico S, Aljohani N, Alfawaz $H$, Alsulaimani M, Al-Othman AM, Alokail MS. Sun exposure, skin color and vitamin D status in Arab children and adults. J Steroid Biochem Mol Biol 2016 doi: 10.1016/j.jsbmb.2016.05.012.

34. Baroncelli GI, Bereket A, El Kholy M, Audi L, Cesur Y, Ozkan B, Rashad M, Fernandez-Cancio M, Weisman Y, Saggese G, Hochberg Z. Rickets in the Middle East: role of environment and genetic predisposition. $J$ Clin Endocrinol Metab 2008;93:1743-1750. Epub 2008 Feb 19

35. Kelishadi R, Marateb HR, Mansourian M, Ardalan G, Heshmat R, Adeli $\mathrm{K}$. Pediatric-specific reference intervals in a nationally representative sample of Iranian children and adolescents: the CASPIAN-III study. World J Pediatr 2016;12:335-342. Epub 2015 Dec 18

36. Soliman A, Kalra S. Adaptation to vitamin D deficiency: Age specific clinical presentations. Indian J Endocrinol Metab 2013;17:775-779.

37. Soliman AT, De Sanctis V, Elalaily R, Bedair S, Kassem I. Vitamin D deficiency in adolescents. Indian J Endocrinol Metab 2014;18:9-16. 